\title{
ANALISIS PENGARUH CORPORATE SOCIAL RESPONSIBILITY TERHADAP RETURN SAHAM DENGAN ROE SEBAGAI VARIABEL MODERATING PADA INDEKS LQ-45
}

\author{
Nofimbi Fitriani ${ }^{1}$, \\ Ali Sadikin², \\ Amalia Wahyuni ${ }^{3}$
}

\begin{abstract}
This research type is a causality with the aim of analyzing the effect of Corporate Social Responsibility on stock returns with profitability as a moderating variable on the LQ-45 Stock Index during the 2013-2017 period. The research population is all companies listed in the LQ-45 Index on the Indonesia Stock Exchange during 2013-2017. The sampling using purposive sampling method with a total sample of 23 companies. Data of this research is quantitative type with data analysis techniques consisting of descriptive analysis, testing classic assumptions, moderating regression analysis, and testing hypotheses. The results showed that there was a significant positive effect on testing the effect of Corporate Social Responsibility on Stock Returns. While the high or low profitability (Return on Equity) is considered unable to moderate the influence of Corporate Social Responsibility on Stock Returns because of the large expenditure incurred for Corporate Social Responsibility can have a negative impact on business operations that will reduce the level of profitability obtained by the investor.
\end{abstract}

Keywords : Corporate Social Responsibility, ROE, Stock Return, 


\section{PENDAHULUAN}

Peraturan pemerintah telah menjelaskan bahwa suatu badan usaha wajib melaksanakan tanggung jawab sosial perusahaan, walaupun sudah jelas tertera Peraturan Pemerintah mengenai tanggung jawab sosial perusahaan terhadap perseoraan terbatas, namun sangat disayangkan perusahaan-perusahaan di Indonesia masih sedikit melakukan program tanggung jawab sosial atau corporate social responsibility dengan benar dan bersungguh-sungguh, masih banyak perusahaanperusahaan yang kurang memperdulikan masalah lingkungan sosialnya, hal ini dapat dilihat pada Program Penilaian Kinerja perusahaan (PROPER) tahun 2013-2014 yang diselenggarakan oleh Kementerian Lingkungan Hidup dan Kehutanan sebagai berikut:

Gambar 1.1

Program Penilaian Kinerja Perushaaan (PROPER) tahun 2013-2014

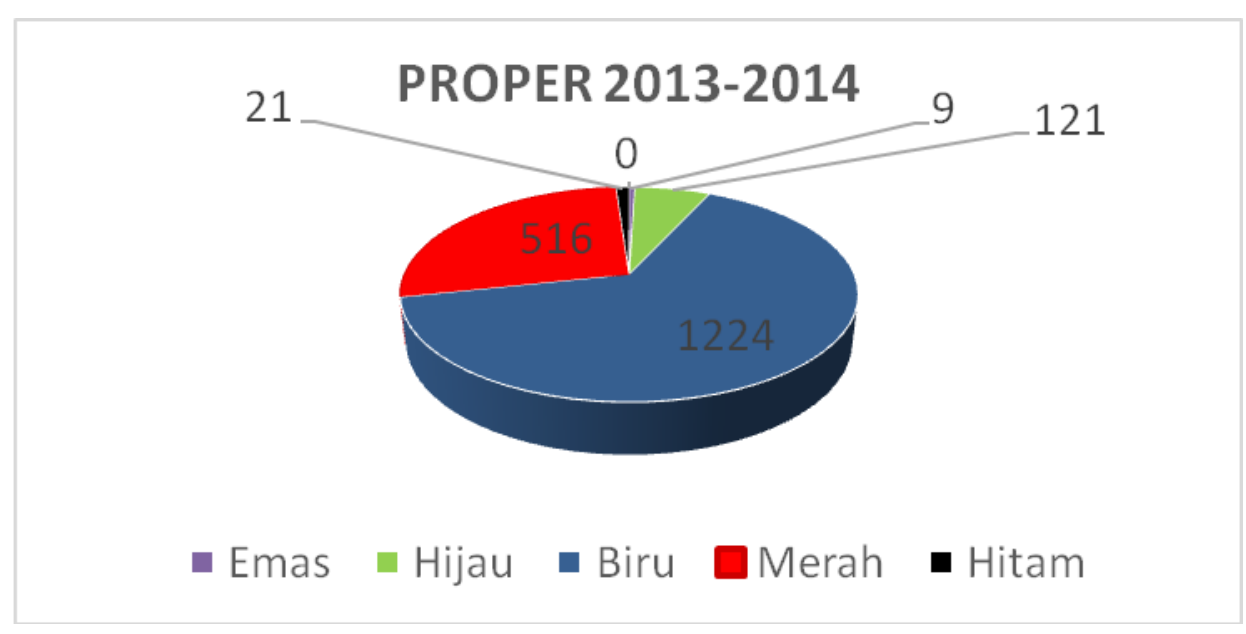

Sumber www.menlh.go.id Data diolah 2019

Dari data kasus di atas dapat disimpulkan bahwa masih banyak perusahaan yang melakukan tanggung jawab sosialnya kurang bersungguh-sungguh dan hanya taat pada peraturan saja, hal ini ditunjukan dari banyaknya perusahaan-perusahaan di Indonesia yang mendapatkan peringkat biru, merah dan hitam dibandingkan dengan perusahaan yang mendapat peringkat emas dan hijau. Pada perushaan yang mendapatkan peringkat emas hanya 9 perusahaan, perusahaan yang mendapatkan peringkat hijau sebanyak 121 perusahaan, sedangkan perusahaan yang mendapatkan peringkat biru sebanyak 1224, dan perushaan yang mendapatkan peringkat merah serta peringkat hitam sebanyak 516, dan 21. Sangat disayangkan perusahaanperusahaan yang benar-benar serius melakukan Tanggung Jawab Sosialnya masih sedikit dibandingkan dengan perusahaan yang hanya sekedar taat melakukan CSR. Padahal apabila dilakukan dengan sungguh-sungguh tanggung jawab sosial dapat memberikan dampak yang positif dalam waktu jangka panjang. 
Perusahaan yang melaksanakan Corporate Social Responsibility ini tentunya mengeluarkan biaya yang banyak dalam jangka pendek, namun pelaksanaan corporate social responsibility mempunyai manfaat yang positif bagi pihak yang ada di dalam perusahaan maupun pihak yang berada di luar perushaaan dalam waktu jangka panjang. Adapun manfaat pelaksanaan tanggung jawab sosial perusahaan atau corporate social responsibility ini yaitu dapat meningkatkan citra perusahaan. Ketika citra perusahaan itu bagus maka loyalitas konsumen akan terbangun sehingga konsumen tentunya memiliki rasa kepercayaan dan berkeinginan untuk membeli produk yang telah dihasilkan perusahaan tersebut. Semakin diminatinya produk tersebut maka profit yang dihasilkan perusahaan tersebut juga akan meningkat.

Profitabilitas merupakan kemampuan perusahaan untuk memperoleh laba yang berhubungan dengan penjualan, total aktiva maupun modal sendiri (Sartono, 2001, p. 122). Pengukuran profitabilitas perusahaan dapat dilakukan salah satunya menggunakan rasio Retturn On Equity. Rasio ini merupakan rasio yang digunakan untuk menghitung laba untuk para pemegang saham. Semakin tinggi ROE perusahaan maka semakin tinggi pula laba yang dihasilkan untuk para pemegang saham. Perusahaan yang dapat menghasilkan laba tinggi maka perusahaan tersebut merupakan perusahaan yang diminati oleh investor, sehingga permintaan saham akan pun meningkat, apabila permintaan meningkat tentunya harga saham juga akan meningkat. Ketika harga saham meningkat maka return saham juga akan mengalami peningkatan.

Perusahaan yang memiliki CSR yang baik serta ditambah dengan peningkatan profitabilitas maka secara tidak langsung return saham juga akan ikut terpengaruh. Return saham merupakan hasil yang diperoleh dari suatu investasi. Return saham dapat berupa return realisasian yaitu return yang sudah terjadi atau return ekspektasi merupakan return yang harapkan pada masa yang akan datang (Hartono, 2013, p. 205). Return saham dapat dihitung dengan menggunakan data masa lalu atau data historis. Perhitungan return terdiri dari Capital Gain (Loss) dan yield. Capital Gain (Loss) merupakan selisih untung atau rugi dari harga investasi sekarang dengan harga investasi periode yang lalu. Apabila selilih yang didapat dari harga investasi yang awal dengan harga jual yang sekarang lebih tinngi maka investor mendapat keuntungan disebut capital gain. Namun apabila harga investasi awal lebih tinggi dari pada harga jual sekarang maka investor mengalami kerugian atau sering disebut sebagai Capital Loss. Untuk menghindari risiko investasi maka seorang investor dapat memilih perusahaan yang diakui kinerjanya, seperti perusahaan yang terdaftar di indeks saham LQ-45.

Indeks LQ-45 merupakan salah satu indeks yang tercatat di Bursa Efek Indonesia. Indeks LQ-45 terdiri dari 45 saham yang paling aktif diperdagangkan. Pertimbanganpertimbangan yang mendasari pemilihan saham yang masuk di indeks LQ-45 adalah likuiditas dan kapitalisasi pasar. 
Penelitian terdahulu yang telah melakukan penelitian baik mengenai corporate social responsibility, profitabilitas, dan return saham yang menunjukan hasil yang berbedabeda. Penelitian yang dilakukan oleh Nur Fitri Juli Nitasari (2016) yang menyatakan bahwa tidak dapat pengaruh antara Corporate Social Responsibility terhadap return saham dan profitabilitas tidak dapat memoderasi pengaruh Corporate Social Responsibility oleh return saham. Hasil penelitian yang dilakukan oleh Damar Adriawan (2015) dan penelitian yang dilakukan oleh Ida Bagus Gede Waisaka Putra dan Imade Karya Utama (2015) menunjukan hasil yang berbeda dari hasil penelitian sebelumnya, hasil penelitian ini menunjukan bahwa variabel corporate social responsibility berpengaruh terhadap return saham. Penelitian lain yang dilakukan oleh Abdul Karim (2015) dan penelitian yang dilakukan oleh Margareta Rizivia Putri, Sutopo, dam Enny Istanti menunjukan hasil bahwa profitabilitas berpengaruh terhadap return saham. Penelitian yang dilakukan oleh Indri Suryani \& Astri Fitria (2014) menyatakan bahwa Corporate Social Responsibility berpengaruh terhadap nilai perusahaan dan profitabilitas sebagai variabel moderating dapat mempengaruhi hubungan antara CSR dan nilai perusahaan.

\section{TINJAUAN PUSTAKA}

\section{Asimetri Informasi}

Asimetri informasi merupakan suatu keadaan dimana manajer memiliki akses informasi atas prospek perusahaan yang tidak dimiliki oleh pihak luar perusahaan (pemegang saham). Sesuai dengan pengertian asimetri informasi menurut Suwarjono (2014:584). Terdapat dua macam asimetri informasi yaitu:

1. Adverse selection, yaitu bahwa para manajer serta orang-orang dalam lainnya biasanya mengetahui lebih banyak tentang keadaan dan prospek perusahaan dibandingkan investor pihak luar.

2. Moral hazard, yaitu bahwa kegiatan yang dilakukan oleh seorang manajer tidak seluruhnya diketahui oleh pemegang saham maupun pemberi pinjaman.

\section{Teori Sinyal (Signaling Theory)}

Signaling theory merupakan sinyal-sinyal informasi yang dibutuhkan oleh investor untuk mepertimbangkan dan menentukan apakah para investor akan menanamkan sahamnya atau tidak pada perusahaan yang bersangkutan (Suwardjono, 2005).

\section{Initian Public Offering (IPO)}

Perusahaan yang membutuhkan dana atau emiten dapat menjual surat berharganya di pasar modal. Surat berharga yang baru dikeluarkan oleh perusahaan kemudian dijual di pasar perdana (primary market). Pasar perdana merupakan tempat atau sarana bagi perusahaan yang untuk pertama kali menawarkan saham atau obligasi ke masyarakat umum (Samsul, 2006). 


\section{Underpricing}

Underpricing dapat diartikan sebagai selisih harga penutupan (closing price) dihari pertama pasar sekunder dengan harga penawaran umum (offering price). Sehingga, apabila harga penawaran perdana saham lebih rendah dari harga saat penutupan di hari pertama pasar sekunder maka saham tersebut dikatakan mengalami underpricing. Underpricing dapat diukur dengan rumus sebagai berikut (Triani, 2006) :

Initial return $(\%)=\frac{\text { Harga Closing Pasar Sekunder-Harga IPO }}{\text { Harga IPO }} \times 100 \%$

Keterangan:

Harga IPO : Harga saat melakukan IPO di pasar perdana

Harga Closing : harga penutupan 1 (satu) hari setelah IPO di pasar sekunder

Debt to Equity Ratio (DER), Menurut Kasmir (2016:157) Dept to Equity Ratio (DER) adalah rasio yang digunakan untuk menilai utang dengan ekuitas.

Earning per Share (EPS), EPS mencerminkan jumlah uang yang diperoleh untuk setiap lembar saham perusahaan. Hasil empiris menunjukkan bahwa semakin tinggi EPS, semakin tinggi pula harga saham.

Reputasi Underwriter, menurut Suyatmin (2006) semakin tinggi reputasi underwriter maka mencerminkan resiko perusahaan IPO tersebut rendah serta rendah pula tingkat ketidakpastian saham dimasa mendatang, sehingga tingkat underpricingnya pun juga rendah (Aini, 2013). Ukuran Perusahaan total aset, total penjualan yang dicapai oleh perusahaan dalam suatu periode serta kapitalisasi pasar (Gunawan, 2015). Return on Assets Return on Assets (ROA) adalah kemampuan perusahaan dalam menghasilkan laba. Hendy M. Fakhruddin (2008:80).

\section{METODE PENELITIAN}

Ruang lingkup penelitian ini adalah Indeks LQ-45 periode 2013-2017, indikator yang digunakan adalah Pengungkapan Corporate Social Responbility, Profitabilitas yang menggunakan variabel Return On Equity, dan Return Saham. Jenis penelitian ini adalah penelitian kausalitas. Hubungan kausal adalah hubungan yang bersifat sebab akibat (Sugiyono, 2016, p. 37).Objek penelitian ini adalah indeks LQ-45 yang terdaftar di Bursa Efek Indonesia periode 2013 sampai dengan periode 2017. Populasi dalam penelitian ini adalah seluruh perusahaan yang terdaftar dalam Indeks LQ-45 di Bursa Efek Indonesia tahun 2013 hingga tahun 2017. Pengambilan sampel dalam penelitian ini menggunakan metode purposive sampling dengan menetapkan kriteria sampel. Kriteria yang akan dijadikan sampel penelitian yaitu:

1. Perusahaan yang terdaftar pada Indeks LQ-45 selama periode pengamatan yaitu periode 2013 hingga periode 2017.

2. Perusahaan yang konsisten masuk pada Indeks LQ-45 periode selama periode pengamatan. 
3. Perusahaan yang mengungkapkan aktivitas Corporate Social Responsibility secara konsisten selama periode pengamatan.

Didalam penelitian ini variabel dependennya adalah corporate social responsibility. Indikator yang digunakan untuk mengukur corporate social responsibility dengan menggunakan variable dummy yaitu: Score 0: Jika perusahaan tidak mengungkapkan item pada daftar pertanyaan. Score 1: Jika perusahaan mengungkapkan item pada daftar pertanyaan. Pengukuran kemudian dilakukan berdasarkan indeks pengungkapan masingmasing perusahaan yang dihitung melalui jumlah item yang sesungguhnya diungkapkan perusahaan dengan jumlah semua item yang mungkin diungkapkan. Rumus CSR dapat diuraikan sebagai berikut:

$$
\operatorname{CSRI}_{j}=\frac{\boldsymbol{\Sigma} \boldsymbol{X}_{i j}}{\boldsymbol{n}_{j}}
$$

Keterangan:

$C S R I_{j}=$ Corporate Social responsibility Disclosure index perusahaan.

$\Sigma X_{i j}=$ Jumlah item corporate social responsibility yang diungkapkan perushaan.

$n_{j}=$ Jumlah item berdasarkan GRI G-4 berjumlah 91.

Return saham adalah hasil keuntungan (Capital Gain) atau kerugian (Capital Loss) yang diperoleh dari hasil investasi dalam kurun waktu tertentu (Hartono, 2013, p. 206).

$$
\text { Return saham }=\frac{\left(P_{t}-P_{t-1}\right)}{P_{t-1}}
$$

Dimana:

Return Saham = selisih dari harga investasi sekarang relative dengan harga periode yang lalu.

$\mathrm{P}_{\mathrm{t}} \quad=$ harga saham pada investasi sekarang

$\mathrm{P}_{\mathrm{t}-1} \quad=$ harga saham pada investasi periode lalu.

Variabel moderating pada penelitian ini adalah Profitablitas atau kemampuan memperoleh laba adalah suatu ukuran dalam persentase yang digunakan untuk menilai sejauh mana perusahaan mampu menghasilkan laba pada tingkat yang dapat diterima Agus Sartono (2001, p. 122). Profitabilitas dapat diukur dengan rasio keuangan yaitu:

$$
\text { Return On Equity }=\frac{\text { Earning After Interest and Tax }}{\text { Equity }}
$$

Teknik pengumpulan data menggunakan data dokumentasi yaitu mengumpulkan semua data sekunder berupa laporan tahunan, laporan keuangan dan harga saham selama periode penelitian yaitu periode 2013, 2014, 2015,2016,dan 2017 melalui situs www.idx.co.id. Jenis data yang digunakan dalam penelitian ini yaitu data kuantitatif, data kuantitatif yaitu data yang berupa angka (Sugiyono, 2016, p. 7). Data 
tersebut berupa laporan tahunan, laporan keuangan, dan harga saham. Sumber data dalam penelitian ini menggunakan data sekunder.

\section{KERANGKA KONSEP PENELITIAN}

Kerangka konseptual model dalam penelitian ini disusun berdasarkan kajian teoritis maupun empiris adalah sebagai berikut :

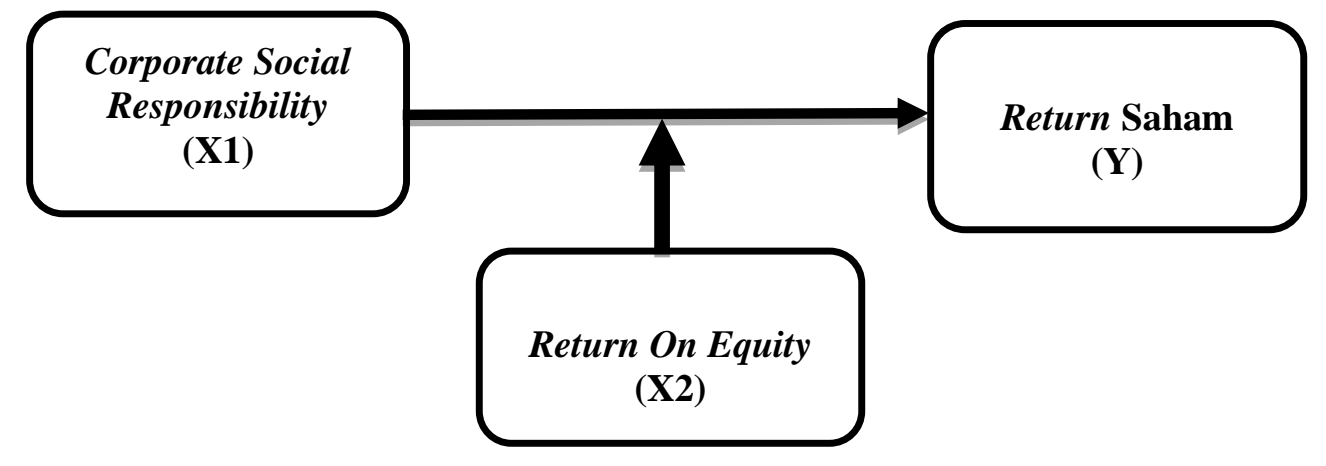

\section{HIPOTESIS PENELITIAN}

Berdasarkan uraian diatas, maka dapat dirumuskan hipotesis sebagai berikut:

H1: Corporate Social Responsibility berpengaruh positif terhadap Return Saham.

H2: Corporate Social Responsibility akan berpengaruh positif terhadap Return Saham apabila ROE suatu perusahaan itu meningkat.

\section{HASIL PENELITIAN DAN PEMBAHASAN}

\section{Uji Validitas dan Reliabilitas}

Uji Validitas dan Reliabilitas instrumen penelitian dilakukan menggunakan program SPSS for windows release 22.0. Berdasarkan Hasil uji Validitas dapat dismpulkan bahwa secara keseluruhan instrumen dari variabel penelitian adalah valid karena memiliki nilai koefesien korelasi $r>0,3$. Demikian juga terhada hasil uji reliabilitas dapat disimpulkan bahwa seluruh nilai alpha lebih besar dari 0,6, sehingga semua instrumen dalam penelitian ini adalah reliabel.

\section{Uji Asumsi Klasik}

\section{Uji Normalitas}

Berdasarkan hasil pengujian statistik bahwa nilai Asymp. Sig (2-tailed) lebih kecil dari 0.05 maka dinyatakan data tidak berdistribusi normal. Maka dari itu dapat dinyatakan bahwa data tersebut terkena gejala normalitas, agar data tersebut dapat normal atau tidak terjadi gejala normalitas maka data tersebut dapat 
dilakukan dengan menggunakan uji outlier data. Berikut ini hasil uji normalitas yang sudah diperbaharui menggambarkan Uji Normalitas dengan menggunakan One-Sample Kolmogorov-Smirnov Test dengan hasil nilai Asymp. Sig. (2-tailed) sebesar $0.987>$ dari 0.05 berarti data terdistribusi normal, sehingga dapat ditarik kesimpulan bahwa asumsi normalitas terpenuhi.

\section{UJi Heteroskedasitisitas}

Deteksi terjadinya heteroskedastisitas dilakukan dengan melihat ada tidaknya pola tertentu pada grafik, dimana sumbu $X$ dan $Y$ yang telah diprediksi, dan sumbu $\mathrm{X}$ adalah residual ( $\mathrm{Y}$ prediksi - $\mathrm{Y}$ sesungguhnya) yang telah di studentized (Ghozali, 2006).

\section{Tabel 5.8}

\section{Uji Heterokedastisitas}

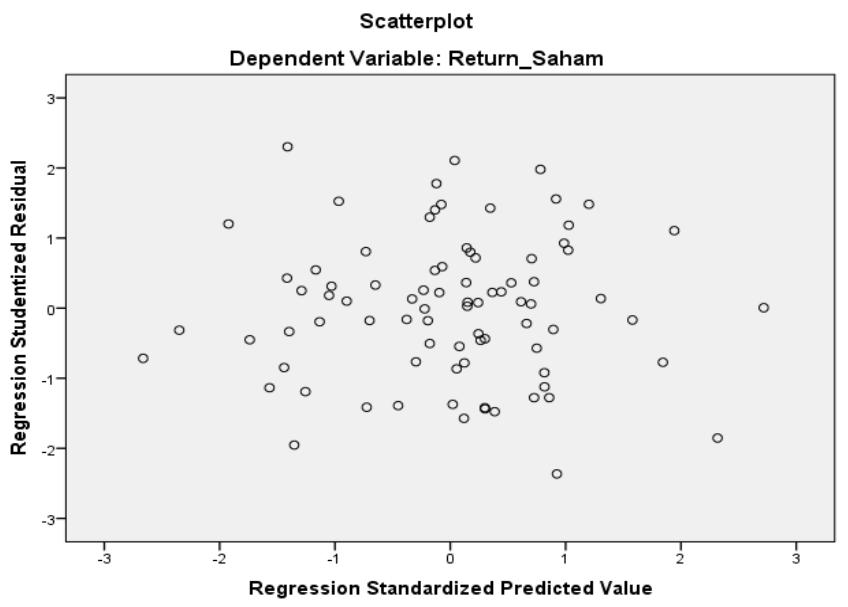

Pada grafik Scatterplot diatas dapat kita lihat bahwa tidak ada pola yang jelas serta titik-titik tersebut menyebar keatas dan kebawah angka 0 pada sumbu y maka dapat ditarik kesimpulan tidak terjadi gejala heterokedastisitas. Hasil grafik scater plot terlihat bahwa penyebaran data menyebar di atas dan di bawah angka 0 dan tidak membentuk pola tertentu, yang berarti tidak terjadi heteroskedastisitas.

\section{Uji Multikolinearitas}

Deteksi gejala multikolinearitas adalah dengan melihat nilai tolerance dan nilai Variance Inflation Factor (VIF). Jika nilai Tolerance $\leq 0.10$ dan nilai $\geq$ VIF 10, maka menunjukan adanya gejala multikoliniaeritas. Jika nilai Tolerance $\geq 0.10$ dan nilai VIF $\leq 10$, maka dapat dikatakan tidak terjadi gejala multikolinearitas. Dari hasil pengujian multikolinearitas bahwa nilai tolerance pada variabel Corporate Social Responsibility, variabel Return On Equity dan Variabel moderating memiliki nilai Tolerance $\geq 0.10$ dan nilai VIF variabel Corporate Social 
Responsibility, variabel Return On Equity dan Variabel moderating memiliki nilai $\leq 10$, maka dapat ditarik kesimpulan bahwa tidak terjadi gejala multikoliniearitas.

\section{Uji Autokolerasi}

Berdasarkan hasil statistik menggambarkan bahwa uji autokolerasi menunjukan bahwa nilai Durbin Waston sebesar 2.571, dengan menggunakan nilai signifikansi $\alpha=0.05$, jumlah sampel $(n)=85$ dan dan jumlah variabel independen $(k)=3$, pada tabel Durbin Watson diketahui bahwa nilai $\mathrm{dL}=1.59952$ dan nilai $\mathrm{dU}=1.69568$. Oleh karena nilai nilai 4-dL sebesar 2.40048 lebih kecil dari nilai durbin waston 2.571 dan lebih kecil dari 4, maka dapat disimpulkan bahwa $2.20048<2.571<4$ menyatakan bahwa terjadi autokolerasi negatif $(4-\mathrm{dL}<\mathrm{dW}<4)$, sehingga dilakukan pengobatan autokolerasi menggunakan metode CohraneOurcut. Bedasarakan hasil pengujian menggunakan metode Cohrane-Ourcut diketahui nilai durwin waston sebesar 2.037 lebih besar dari batas atas (dU) 1.69568 dan kurang dari 4 - 1.69568 (4 - dU). Maka dapat disimpulkan bahwa $1.69568<2.037<(4-1.69568)$ menyatakan bahwa tidak terdapat autokolerasi positif maupun negatif ( $\mathrm{dU}<\mathrm{dW}<4-\mathrm{du})$. Hal ini menunjukan bahwa tidak terjadi autokolerasi antar variabel sehingga model regresi layak digunakan.

\section{HASIL ANALISIS REGRESI LINEAR BERGANDA}

Analisis regresi yang dilakukan dalam penelitian ini adalah Moderated Regression Analysis (MRA). Analisis tersebut digunakan untuk mengetahui apakah ada pengaruh CSR terhadap return saham dan apakah profitabilitas dapat memoderasi pengaruh CSR terhadap return saham.

Tabel 5.9

Hasil Uji Analisis Regresi

Coefficients $^{\mathrm{a}}$

\begin{tabular}{|c|c|c|c|c|c|c|}
\hline \multirow[b]{2}{*}{ Mode } & & \multicolumn{2}{|c|}{ Unstandardized Coefficients } & \multirow{2}{*}{$\begin{array}{c}\begin{array}{c}\text { Standardized } \\
\text { Coefficients }\end{array} \\
\text { Beta }\end{array}$} & \multirow[b]{2}{*}{ t } & \multirow[b]{2}{*}{ Sig. } \\
\hline & & $B$ & Std. Error & & & \\
\hline \multirow[t]{4}{*}{1} & (Constant) & 3.804 & 4.676 & & .813 & .418 \\
\hline & CSR & 7.760 & 3.728 & .251 & 2.081 & .041 \\
\hline & ROE & 24.460 & 8.368 & .329 & 2.923 & .005 \\
\hline & MODERATING & 6.827 & 6.290 & .133 & 1.086 & .281 \\
\hline
\end{tabular}

a. Dependent Variable: Return_Saham

Sumber: Hasil SPSS 21, data diolah kembali 2019

Berdasarkan Tabel diatas maka persamaan model regresi dalam penelitian ini adalah Return Saham = 3.804+7.760 CSR+24.460 ROE+6.827 (CSR-ROE) 


\section{Uji Hipotesis Penelitian}

\section{Uji Statistik T}

Uji statistik $\mathrm{t}$ menunjukkan seberapa jauh pengaruh variabel bebas (variabel independen) secara individual dalam menerangkan variabel terkait (variabel dependen) (Ghozali, 2013, p. 98). Dasar pengambilan keputusan uji $\mathrm{t}$ dengan cara membandingkan nilai $\mathrm{t}$ hitung dengan $\mathrm{t}$ tabel serta membandingkan nilai signifikansi. Berikut hasil uji t dengan menggunakan program SPSS:

\section{Pengaruh Corporate Social Responsibility terhadap Return Saham}

Berdasarkan hasil penelitian menggunakan uji $\mathrm{t}$ menunjukan bahwa nilai $\mathrm{t}$ hitung 2.081 dan nilai signifikansi sebesar 0.041, hal ini menunjukan bahwa nilai $\mathrm{t}$ hitung lebih sebesar 2.081 lebih besar dari pada t tabel sebesar 1.663, maka Ho ditolak dan $\mathrm{H}_{1}$ diterima. Tingkat signifikansi dalam penelitian ini sebesar 0.05 yang berarti 0.041 lebih kecil 0.05. Berdasarkan penjelasan tersebut dapat disimpulkan bahwa Corporate Social Responsibility berpengaruh positif dan signifikan terhadap Return Saham.

2. Pengaruh Corporate Social Responsibility terhadap Return Saham dengan ROE sebagai variabel moderating.

Berdasarkan hasil penelitian menggunakan uji $\mathrm{t}$ menunjukan bahwa nilai $\mathrm{t}$ hitung sebesar 1.089 dan nilai signifikansi sebesar 0.281, hal ini menunjukan bahwa nilai $\mathrm{t}$ hitung lebih sebesar 1.089 lebih kecil dari pada $\mathrm{t}$ tabel yaitu sebesar 1.663, maka $\mathrm{H}_{0}$ diterima dan $\mathrm{H}_{1}$ ditolak. Tingkat signifikansi penelitian ini sebesar 0.05 yang berarti 0.281 lebih besar dari pada 0.05 , berdasarkan penjelasan tersebut dapat ditarik kesimpulan bahwa Profitabilitas (Return On Equity) tidak dapat memoderasi pengaruh Corporate Social Responsibility terhadap Return Saham.

\section{Uji R ${ }^{2}$ (Koefesien Determinasi)}

Uji Koefesien determinasi dilakukan untuk mengetahui seberapa jauh kemampuan model dalam menjelaskan variabel independen terhadap perubahan variabel dependen. Nilai $R^{2}$ berkisar antara 0 (nol) samapi 1 (satu). Nilai $R^{2}$ yang kecil menunjukan bahwa variabel independen menjelaskan perubahan variabel dependen terbatas. Jika variabel $\mathrm{R}^{2}$ mendekati 1 (satu) maka variabel independen mampu memberikan semua informasi yang dibutuhkan untuk memprediksi variabel dependen (Ghozali, 2013). 
Tabel 5.10

Hasil Uji R² Koefesien Determinasi

Model Summary ${ }^{\text {b }}$

\begin{tabular}{|l|l|r|r|r|}
\hline Model & $\mathrm{R}$ & R Square & $\begin{array}{c}\text { Adjusted R } \\
\text { Square }\end{array}$ & $\begin{array}{c}\text { Std. Error of } \\
\text { the Estimate }\end{array}$ \\
\hline 1 & $.483^{\mathrm{a}}$ & .233 & .204 & 20.74716 \\
\hline
\end{tabular}

a. Predictors: (Constant), MODERATING, ROE, CSR

b. Dependent Variable: Return_Saham

Sumber: Hasil SPSS 21, data diolah kembali dilampiran (2019).

Hasil pada uji R square menunjukan bahwa pengaruh antara variabel idependen terhadap variabel dependen sebesar 0.233 atau $23.3 \%$. artinya bahwa persetanse pengaruh Corporate Social Responsibility, Return On Equity, Moderating sebesar $23.3 \%$ sedangkan sisanya $76,7 \%$ dipengaruhi oleh faktor lain yang tidak dimasukan dalam model regresi ini.

Dari hasil uji statistic Pengaruh Corporate Social Responsibility terhadap Return Saham bahwa Corporate Social Responsibility memiliki pengaruh yang positif dan signifikan terhadap Return Saham., Perusahaan-perusahaan yang melakukan pengungkapan Corporate Social Responsibility secara berkelanjutkan akan mendatangkan banyak manfaat bagi perusahaan salah satunya keunggulan kompetitif yang didapat perusahaan. Semakin banyaknya perusahaan mengungkapkan Corporate Social Responsibility maka semakin menarik minat para investor untuk berinvestasi. Perusahaan yang banyak melakukan kegiatan corporate social responsibility merupakan perusahaan yang memiiki ketersediaan dana yang cukup besar, ketersediaan dana yang cukup besar ini menunjukan bahwa perusahaan dapat mengelola modal dengan produktif, sehingga para investor tidak perlu cemas terhdap kelangsungan usaha perusahaan tersebut. Sehingga informasi-informasi corporate social responsibility yang diungkapkan perusahaan tersebut akan menarik investor dalam berinvestasi, keterminatan investor dalam berinvestasi meningkatkan pembelian saham tersbut secara langsung juga akan menaikan harga saham tersbut yang akan berdampak pada return saham yang didapat. Sehingga dapat dismpulkan bahwa semakin meningkatnya pengungkapan CSR maka akan meningkat pula return saham yang didapatkan.

Demikian juga dari hasil uji statistic Pengaruh Corporate Social Responsibility terhadap Return Saham dengan ROE sebagai variabel moderating bahwa Profitabilitas (Return On Equity) tidak dapat memoderasi pengaruh Corporate Social Responsibility terhadap Return Saham. Hal ini disebabkan karena Pengungkapan Corporate Social Responsibility yang dilakukan perusahaan mengeluarkan biaya tidak sedikit atau 
dapat dikatakan mengeluarkan biaya yang cukup besar, hal ini bisa berdampak negatif pada operasi bisnis, kompensasi manajemen serta dividen yang didapat pada para pemegang saham dalam jangka pendek, dikarenakan dana yang dikeluarkan merupakan dana yang diambil dari profitabilitas perusahaan, sehingga dividen yang didapat oleh pemegang saham pun akan berkurang.

\section{KESIMPULAN}

Corporate Social Responsibility berpengaruh positif dan signifikan terhadap Return Saham, hal ini menunjukan bahwa semakin tinggi tiggkat pengungkapkan Corporate Social Responsibility maka akan meningkatkan Return Saham. Sedangkan Profitabilitas (Return on Equity) tidak dapat memoderasi pengaruh Corporate Social Responsibility terhadap Return Saham. Hal ini disebabkan karena Pengungkapan Corporate Social Responsibility yang dilakukan perusahaan mengeluarkan biaya tidak sedikit atau dapat dikatakan mengeluarkan biaya yang cukup besar, hal ini bisa berdampak negatif pada operasi bisnis, kompensasi manajemen serta dividen yang didapat pada para pemegang saham dalam jangka pendek sehingga menurut para investor pengeluaran biaya tersebut tentunya akan menurunkan tingkat profitabilitas yang akan mereka dapat. Sehingga tinggi atau rendahnya tingkat profitabilitas dan pengungkapan Corporate Social Responsibility yang didapat perusahaan tidak dapat memoderasi Saham .

\section{DAFTAR PUSTAKA}

Adriawan, D. (2015). Pengaruh Corporate Social Responsibility Dan Kinerja Keuangan Terhadap Return Saham Perusahaan Yang Tergabung Di Jakarta Islamic Index. Artikel Ilmiah Mahasiswa, 1-6.

Ghozali, I. (2013). Aplikasi Analisis Multivariate Dengan Program IBM SPSS 21 Update PLS Regresi (7 ed.). Semarang: Badan Penerbit Universitas Diponegoro.

Hartono, J. (2013). Teori Portofolio Dan Analisis Investasi (7 ed.). Yogyakarta: BPFEYOGYAKARTA.

Indri Suryani \& Astri Fitria. (2014). Pengaruh Corporate Sosial Responsibility Terhadap Nilai Perusahaan Dengan Profitabilitas Sebagai Variabel Moderating. Jurnal Ilmu E Riset Akutansi, Vol. 3 No. 10, 1-18.

Karim, A. (2015). Analisis Pengaruh Faktor Internal Dan Eksternal Terhadap Return Saham Perusahaan Manufaktur Yang Terdaftar Di Bursa Efek Indonesia. Media Ekonomi Dan Manajemen, Vol. 30 No.1 , 41-55.

Kartini, D. (2009). Corporate Social Responsibility Transformasi Konsep Sustainability Management Dan Implementasi Di Indonesia (1 ed.). (A. S.Mifka, Ed.) Bandung: PT Refika Aditama. 
Lako, A. (2011). Dekonstriksi CSR \& Reformasi Paragdima Bisnis \& Akutansi. Jakarta: Erlangga.

Margareta Rizivia Putri,Sutopo\& Enny Istanti. (2015). Pengaruh EPS, PBVM DAN ROE Terhadap Return Saham Pada Perusahaan LQ45 Di Bursa Efek Indonesia. Jurnal Manajemen BRANCHMARCK, ISNN: 2407-8239, 77-88.

Nur Fitri Juli Nitasari. (2016). Pengaruh Pengungkapan Corporate Social Responsibility Terhadap Return Saham Dengan Profitabilitas Sebagai Variabel Moderating, 1-76.

Sartono, A. (2001). Manajemen Keuangan Teori dan Aplikasinya (4 ed.). Yogyakarta: BPFEYOGYAKARTA.

Situmeang, I. V. (2016). Corporate Social Responsibility Dipandang Dari Perpespektif Komunikasi Organisasi (1 ed.). Yogyakarta: Ekuilibria.

Sugiyono. (2016). Metode Penelitian Kuantitatif, Kualilatif, dan RED. Bandung: Alfabeta.

Tandelilin, E. (2010). Portofolio Dan Investasi (1 ed.). Yogyakarta: Kaninus.

Utama, I. B. (2015). Pengaruh Pengungkapan Corporate Social Responsibility Dan Informasi Laba Akutansi Pada Return Saham. E-Jurnal Akutansi Universitas Udayana 13.1.

Warsono. (2003). Manajemen Keuangan Perusahaan. Malang: Bayumedia Publishing.

www.globalrepoting.org, (4 April 2018)

www.idx.co.id, (31 Maret 2019)

www.menlh.go.id, (4 April 2018)

www.ojk.go.id (25 May 2019) 